\title{
Den liturgiske eksegese og Grundtvig ${ }^{1}$
}

\author{
Af Christian Thodberg
}

Ved »liturgisk eksegese« forstås det tolkningsprincip, der bestemte den gamle kirkes udvælgelse og forståelse af især evangelietekster som ord og handlinger, der reaktualiseres i gudstjenesten og dermed imødekommer menighedens behov for at være samtidig med de bibelske begivenheder. Ny Testamente er ikke blot den tidlige kirkes historie, men først og fremmest hvad man kunne kalde den ældste menigheds »alterbog «. Af praktiske grunde udvalgte kirken i næste omgang de mest relevante tekster for denne reaktualisering, nemlig i den ældste tekstrække for søn- og helligdage i kirkeåret. Temaet var kort og godt: Idag sker det! Det kommer stærkt til udtryk i den græsk-ortodokse kirke og dens hymner med det tilbagevendende »Simeron«, »idag«:

Jomfruen føder idag

ham, der er over al væren

synger Romanós i sit berømte jule-kontakion. Talrige andre eksempler kunne nævnes. Mest bemærkelsesværdig er naturligvis den ortodokse påskegudstjeneste, der på den stærkeste måde understreger opstandelsens nutid - sikkert i fortsættelse af de første kristnes forventning om Kristi snarlige genkomst just ved daggry påskemorgen efter den lange forudgående nattegudstjeneste. Derudfra tolkes hver søndag året rundt som en opstandelsesdag.

Den græsk-ortodokse kirkes understregning af, at kirken lever i opstandelsens tid, kom i foråret 1837 til at sætte sit afgørende præg på Grundtvigs prædikener og salmer. Det var egentlig ikke uventet, for han var så at sige teologisk disponeret for denne erkendelse, hvilket den følgende fremstilling skal godtgøre.

I den vesterlandske kirke fik den liturgiske eksegese som sagt en markant udformning i forbindelse med det vesterlandske perikopesystem, der var fælles for den romersk-katolske, den anglikanske og den lutherske kirke lige indtil 2. Vatikanerkoncil og den romerske tekstrækkereform, Ordo lectionum (1968), der efterlod det klassiske perikopesystem til de protestantiske kirker f.eks. i 
Danmark - en af grundene til, at jeg ikke er så økumenisk, som andre mener, jeg burde være!

Den klassiske vesterlandske ordning stammer fra den fordeling af epistler og evangelier på bestemte søn- og helligdage, der udformedes i Rom; det er med andre ord et by-romersk system, der blev norm for den vesterlandske kirke i den tidlige middelalder. Iøvrigt er baggrunden ret kompliceret; både den græske og ikke mindste den jerusalemitiske tradition har hver for sig sat deres præg.

Væsentlig for den byromerske tekstordning er den måde, hvorpå valget af tekster bevidst skal reflektere dåben og søndagene før og efter dåbshandlingen, hvad enten den fandt sted ved påsketid eller den 6. januar eller ved pinsetid. Teksterne skal således tolke dåbens betydning, f.eks. den 6 . januar med beretningen om Jesu dåb (Matt. 3,13-17) og epistelteksterne på de følgende søndage fra Romerbrevets 12. og 13. kapitel som formaninger til de nydøbte om at forblive i det nye liv.

I fastetiden bliver billedet endnu tydeligere, fordi dette tidsrum falder sammen med den klassiske dåbsforberedelse, hvor Jesu opvækkelser af døde og helbredelser af syge, især spedalske, og hans exorcistiske handlinger skal understrege dåben som en oprejsning fra døde, en helbredelse af en dødelig sygdom eller en renselse fra synd, mens de parallelle epistellæsninger skal opmuntre dåbskandidaterne til moralsk renhed svarende til den livsomvæltning, som dåben er, f.eks. på midfaste søndag: »Thi I var forhen mørke, men nu er I lys i Herren « (Ef. 5,8).

Det centrale led var naturligvis dåben i natten mellem påskelørdag og påskesøndag, da de hvidklædte nydøbte indførtes i kirken for at modtage nadveren for første gang. Epistlerne i perioden mellem påske og pinse opmuntrer igen de døbte til bestandighed i det nye liv, mens pinsedagene bliver en alternativ dåbstermin, der først slutter på søndag efter pinse, trinitatis søndag, med dåbstemaet (enten Nikodemus-samtalen (Johs 3,1-15) eller dåbsbefalingen (Matt. 28,18-20)).

Således defineres dåben på tre måder: på 6. januar som en fødsel sammen med Kristus, ved påsketid døden og opstandelsen sammen med Kristus og ved pinsetid som modtagelsen af Helligåndens gave. I resten af kirkeåret synes evangelielæsninger om Jesu kraftige gerninger sammen med de mere systematisk ordnede epistler om det nye til dels at have et lignende perspektiv. 
Her ser vi kort fortalt den fulde udfoldelse af »den liturgiske eksegese«, der langt senere blev Grundtvigs homiletiske ledetråd. Den moderne nytestamentlige forskning vil dog i hovedsagen afvise denne eksegese som en from udlægning eller en bevidst kirkelig forfalskning med henblik på at etablere en sakramental magtstilling.

Men i stedet kan man i liturgihistorisk perspektiv ud fra perikopesystemet og de momenter i teksterne, der kom til at bestemme tolkningen med henblik på dåb, spørge, om de samme momenter ikke allerede i nytestamentlig sammenhæng peger i samme retning, for Ny Testamentes tekster er jo udvalgt og redigerede af den tidlige kristne menighed, hvis behov og tolkning af teksterne efter alt at dømme ikke har adskilt sig væsentligt fra interesserne i den menighed, der lidt senere opstillede tekstrækkesystemet.

Med henvisning til et større perikopehistorisk arbejde ${ }^{2}$ skal jeg kort opsummere: Analyserer man beretningerne om Kristi kraftige gerninger, hans helbredelser og dødeopvækkelser, får man øje på en særpræget terminologi, dels en ejendommelig sproglig stereotypi, dels en forekomst af ganske bestemte verber, der i begge tilfælde synes at pege i retning af en dobbelttydighed, f. eks. i forbindelse med verberne "frelse« og »oprejse«: »frelse« kan betyde at redde og at helbrede, men også at frelse i eskatologisk betydning. Verbet »oprejse« er så tæt forbundet med Kristi opstandelse eller oprejsning, at Jesu oprejsning af døde mennesker allerede i den gængse nytestamentlige forskning forstås som en oprejsning til et opstandelsesliv her på jorden, mens den samme forskning ikke vil anerkende den samme betydning, når det »drejer sig om oprejsning af syge - endnu ikke døde mennesker! ${ }^{3}$

Når der i Kolossenserbrevet tales om "I...Faderen, som gjorde os skikkede til at få del i de helliges arvlod i lyset, han, som friede os ud af mørkets magt og førte os over i sin elskede Søns rige« (1,12-13), tænkes efter al sandsynlighed på en bestemt begivenhed, der kun kan identificeres med dåben som en oprejsning til livet. Overhovedet synes de yngre Paulus-breve (Efeser- og Kolossenser-brevene) at betragte dåben som en kraftig handling på linie med den tolkning, som tekstrækken synes at give anledning til.

Dåben som det bagved liggende motiv synes tilmed at kunne kaste nyt lys over visse evangeliske tekster. Det gælder f.eks. beretningen om helbredelsen af den værkbrudne (Markus 2,1-12), hvor helbredelsen på den ene side og tilsigelsen af syndernes forladelse på den anden side stilles op mod hinanden, 
og hvor pointen er, at tilsigelsen af syndernes forladelse er et større vidnesbyrd om Guds magt end helbredelsen. Sagt på en anden måde: for menigheden skal Jesu urbilledlige handling fastslå betydningen af tilgivelsen, der netop er dåbens gave.

Jesu velsignelse af børnene (Markus 10,13-16) er berømt i forskningen i forbindelse med diskussionen om barnedåbens alder og berettigelse, $\mathrm{og}$ i den forbindelse bør forekomsterne af bestemte vigtige interpretamenter ikke overses: (1) Mødrene kommer hen til Jesus med børnene, for at han skulle røre ved dem, og han tog dem i favn, lagde honderne på dem og velsignede dem. Verberne røre ved, lagge hoender på og velsigne hører til de faste ord ved Jesu underfulde handlinger. Beretningen er faktisk en slags »helbredelse« af børnene som en udsat kategori af mennesker, der dermed sættes over i frelsens rige. Barnedåb eller ikke - Jesu handling er ligeså stærk som en dåb!

Det vesterlandske tekstrækkesystem overlevede i hovedsagen reformationen. Men i løbet af 17. og 18. århundrede kom netop beretningerne om Kristi kraftige gerninger i kritisk søgelys. De opfattedes som magiske træk, der skyggede for Bibelen som kristendommens loere. Parallelt hermed afskaffede man i liturgisk sammenhæng forsagelsen og nævnelsen af Djoevelen og i den apostolske trosbekendelse ordet Helvede, ligesom man opfattede bebudelsen, opstandelsen og himmelfarten som »billeder «.

Som gammeldags troende protesterede Grundtvig: Kristendommen stod og faldt med Kristi kraftige gerninger. Men trods sin tro p̊̊, at Bibelen bogstaveligt var Guds ord, blev hans problem, hvor og hvordan Guds ord og Kristi kraftige gerninger angik ham personligt. Teologisk blev spørgsmålet om Guds nærhed Grundtvigs bestandige problem livet igennem. Enkelt udtrykt: Hvor taler Gud til mig?

Det var et jeg-du-forhold, Grundtvig savnede i kristendommen. Selv den ypperste prædikant kunne ikke etablere det forhold. Spørgsmålet var stadig: Hvor taler Gud til mig?

Løsningen fandt Grundtvig i dåben - ikke i dåbens ydre handling, men i det lutherske dåbsrituals ord, som han opfattede som Guds ord til den enkelte. Det gjaldt alle ritualtekstens personligt relaterede led: »Modtag det hellige korsets tegn både for dit ansigt og for dit bryst ...«, »Forsager $d u$ Djævelen og alle hans gerninger ...», »Tror $d u$ på Gud Fader den almægtige ...«, »Jeg døber dig ...«, »Den almægtige Gud, vor Herres Jesu Kristi Fader, som nu har genfødt dig ved 
vand og Helligånden og har eftergivet dig alle dine synder, han styrke dig med sin nåde til det evige liv, «Fred være med dig!«. Det gjaldt i nadveren selve Indstiftelsesordene, hvor vægten ganske vist ikke ligger på $d u$ og dig, men på I og jer.

Således bør efter min mening Grundtvig såkaldte »mageløse opdagelse« i praksis forstås. For en umiddelbar betragtning kan Grundtvigs løsning af sit teologiske grundproblem ligne en pedantisk og primitiv ritualisme, men »den mageløse opdagelse« skal ses i forlængelse af Grundtvigs tidligere overvejelser om modersmålets betydning: »Hjertesproget « kan alene formidle kærligheden mellem forældre og børn og mellem ægtefæller. Og kristendommens »hjertesprog« er de ritualtekster, hvor Gud utvetydigt tilsiger menigheden sin kærlighed og syndernes forladelse.

Hermed sætter Grundtvig bevidst dåbens og nadverens ord over Bibelen, for når Bibelen står alene som udtryk for Guds ord, er kristendommens indhold udleveret til forskellige teologiske skriftfortolkeres anskuelser. Allerede Grundtvig var stærkt anfægtet af den historisk-kritiske forsknings tidligste resultater.

Til gengæld opstod tilsyneladende et andet problem: Når Bibelen blev sat i skyggen af ordene ved dåben og nadveren, skulle man mene, at også prædikenen over kirkeårets forskellige tekster blev problematiseret, for i grunden var det jo kun ritualordene, der "prædikede«. Sagt anderledes: Fik man ikke en "ritualords-fundamentalisme i stedet for en bibel-fundamentalisme?

Sådan gik det ikke i Grundtvigs tilfælde, for netop ritual-ordene svarer jo til den centrale apostolske forkyndelse: Jesus Kristus død og opstanden for os! Næsten programmatisk illustrerer han sit synspunkt i prædikenen på 16. søndag efter trinitatis 1836 over en af sine mest elskede tekster, evangeliet om enkens søn i Nain (Lukas 7,11-17). Jesu ord til den sørgende enke: „Græd ikke!« og til den døde søn: "Stå op!« skaber hverken trøst eller liv, når de bliver sagt af mennesker idag. De ord gjaldt kun dem, Jesus talte til dengang. Hvor lyder så Jesu kraftige ord til os nu? Grundtvig svarer"

Jeg siger: saa vist som Jesus Christus er Guds eenbaarne Søn og saavist som den Daab, vi døbes med, og den hellige Nadvere, vi indbydes til er indstiftede af Ham, saavist er han ogsaa selv tilstæde overalt, hvor der døbes, bespises og lædskes paa hans Vegne og med hans Ord, og det er ham selv, der taler til dem, der vil høre hans Røst, ham selv, der spørger: troer du, 
ham selv der siger til den Troende: jeg døber dig i Navnet Faderens og Sønnens og den Hellig-Aands, ham selv der byder de Troende og Døbte til sit Bord og siger til dem: tager hen og æder, det er mit Legeme, som gives for eder, drikker alle heraf denne er den ny Pagts Kalk i mit Blod, som udøses for eder til Syndernes Forladelse. Det er ham selv, vor Herre Jesus Christus, som taler disse Ord ved sine Tjeneres Mund, som er dertil udsendte, og enhver som annammer disse Ord og giemmer dem som Guds Ord i sit Hjerte, skal erfare, de er Liv, er Aand, har Aanden i sig, som gjør levende, den Hellig-Aand, som er Christi sande Stat-Holder paa Jorden, og som Sandhedens Aand Eet med Herren ... Ja dette er mit Vidnesbyrd, og derfor sagde jeg tit og gientager, at i Aanden har Herren mødt sin Menighed, som han i Dagens Evangelium mødte Enken med hendes Eenbaarne, har standset Baaren sagt til Kirken vor Moder græd ikke og ved at opvække sit Ord ved Naade-Midlerne af Døde, opvakt Kirkens Haab og Trøst, som i Grunden er ham selv det levende Guds Ord.

Det var Jesus, der dengang trøstede den sørgende enke og oprejste hendes døde søn. Næsten som et omkvæd hedder det her: «Det er ham selv, der taler!« Det er Jesus, der nu i sin menighed udretter de samme gerninger og trøster de sørgende og skænker de døde livet ved at gentage de ord, der nu lyder ved dåben og nadveren. De personligt relaterede ritualord gentager dåbens og nadverens tilsagn. Ved at lade ritualordene udtrykke de kraftige gerninger, som Jesus gjorde dengang, fâr Jesu kraftige gerninger $n u$ en utvetydig personlig adresse.

Bibelens beretninger tolkes og udlægges af ritualordene, der gør Jesu kraftige gerninger nærværende i menigheden. Hvis Bibelen ikke forkyndes på den måde, er det en død tekst: "Den blotte Beskrivelse og Læsning" af Bibelen nytter nemlig ikke; Kristus er den samme til evig tid og gør stadigvæk i gudstjenesten de samme kraftige gerninger, som han gjorde fra begyndelsen. ${ }^{5}$

Derfor protesterede Grundtvig mod Oplysningen og Rationalismen, der ville bortforklare Jesu undergerninger som "magiske rester«, ligesom han tog til genmæle mod "den nye oplysning" med D.F. Strauss' "Das Leben Jesu» (1835): »Nei, alt Saadant vil vor Troes oplyste Modstandere belee, som Barnagtigheder fra Menneske-Forstandens Drenge-Aar og løfte Historien om Jesus Christus, Gud og Mand, hans Mirakler, Opstandelse og Himmel-Fart til Skyerne, som Stadfæstelse paa deres egne Drømme, som det urokkelige Beviis paa 
den guddommelige og menneskelige Naturs Grund-Eenhed, og som det straalende Forbillede paa Menneske-Aandens glimrende Seier over Døden og evige Selv-Forgudelse! ${ }^{6}{ }^{6}$

Tværtimod må den kristne kirke fastholde, at med dåben og nadveren sker for den enkelte det mirakel, hvorpå troen beror, og dåben gavner intet, »....med mindre Man troer, hvad Daabs-Pagten kræver, altså tilligemed det store Mirakel, at Daaben er et Igienfødelsens og Fornyelsens Bad i den Hellig-Aand, de Mirakler hvorved den er blevet det, som jo er, at hans eenbaarne Søn, der skabde Himmel og Jord, blev undfangen af den Hellig-Aand og født af Jomfru Marie, at han døde men opstod igien den tredie Dag, foer til Himmels og skal komme igien at dømme Levende og Døde. - Dette er Grund-Miraklerne som alle Christne skal troes. ${ }^{7}$

Herudfra udfoldes nu Grundtvigs »liturgiske eksegese«. Det er Kristi undergerninger i evangelierne, der reaktualiseres ved hans stadige nærværelse i menigheden, men vel at mærke i kraft af ordet: "... ikke som om han var i Vandet, i Brødet og i Vinen, men som Den, hvis Ord er Liv og Aand, ....$^{8}$ Det er endnu engang de bestemte ritual-ord, der står i centrum, og som bliver den homiletiske nøgle til Grundtvigs prædikener.

Når officeren fra Kapernaum, der beder Jesus helbrede sin tjener, ud fra sin erfaring om den militær kommandovej siger: "Siig kun et Ord, saa helbredes min Tjener ... « (Matt. 8,8), svarer han i grunden bekræftende på det spørgsmål om at forsage og at tro, der lyder ved dåben: ॥gaae fra Djævelen, saa gaaer vi, kom hid til mig, saa kommer vi, tag dit Kors op og følg mig, saa gør vi det, og naar Han siger, giør det, saa skal du leve, da ikke blot troe vi det, men da leve vi med Ham, saa sand og saa godt, som Han lever med Faderen «. ${ }^{9}$

For at vende tilbage til, hvad jeg begyndte med: Grundtvigs »liturgiske eksegese « får sit mest markante udtryk i hans tolkning af beretningen om Jesu velsignelse af børnene (Markus 10, 13-17), der i den nytestamentlige sammenhæng bør opfattes som en underberetning, en helbredelse af børn som en udsat gruppe af mennesker, der dermed rejses op til livet. Ligesom de andre underberetninger forstår Grundtvig også denne beretning med henblik på dåben ganske særligt som den indgår i det lutherske dåbsritual, hvor vægten ligger på slutningen $(10,16)$ og overgangen til det følgende Fadervor: 
Og han tog dem i favn og lagde hænderne på dem og velsignede dem. Derfor vil vi også hjælpe dette barn til hans velsignelse ved vor andægtige bøn til Gud.

Præsten lægger sin hånd på barnets hoved og beder Fadervor.

For Grundtvig fik Fadervor på den måde den samme status som de øvrige ritual-ord. Det er et ord henvendt til den enkelte - eller rettere sagt: det ord, der bliver den bøn, som Jesus siger og beder for den enkelte. Således bliver Jesu forbøn i dåbsritualet det stærkeste udtryk for meddelelsen af Helligånden: "Ånden selv går i forbøn for os med uudsigelige sukke« (Rom. 8,26b).

Når præsten lægger hånden på barnets hoved, gentager han, hvad Jesus gjorde, og barnet lægges med den bøn, som Jesus beder for ham eller hende, over i Guds favn, der for Grundtvig er det tryggeste sted, som den døbte i hver en alder kan bede sig tilbage til med Fadervor i Jesu navn og dermed genopleve sin dåb, således som det i en af Grundtvigs med kendte salmer, Sov sødt, barnlille får et bevægende udtryk.

Hermed er ringen sluttet. Den liturgihistoriske forsknings tese er, at den liturgiske eksegese har sin ret allerede i Ny Testamente, og at de yngre Paulusbreve i den sammenhæng rehabiliteres, fordi de bliver nøglen til den samme forståelse af Jesu undergerninger med henblik på dåb. $\mathrm{Og}$ endelig betyder Grundtvigs ihærdige forsøg på at finde det sted, hvor Gud taler til ham, at han intuitivt genopdager den gammelkirkelige forståelse af sammenhængen mellem Jesu kraftige gerninger og dåb - en moderne udfordring til den nytestamentlige forskning og prædikenen idag.

\section{Noter}

1. Forelæsning 26. august 2000 (Presenting Grundtvig. International Consultation on N.F.S. Grundtvig. University of York, England: 24 - 27 August 2000).

2. Bibelsk Teologi (red. Sigfred Pedersen), Århus 2000, s. 257-299.

3. Theologisches Wörterbuch zum Neuen Testament VI, s. 395.

4. Grundtvigs Pradikener (= GP), bind 9 (1835-36), Kbh. 1985, s. 310.

5. GP 6, s. 141.

6. GP 9, s. 232-33.

7. GP 6, s. 274.

8. GP 9, s. 86 .

9. GP 9, s. 120 . 